\title{
Monks, laity and the prospect of self-sufficiency: Souflar Metochi of Vatopedi Monastery ${ }^{1}$
}

\author{
Andreas Bouroutis \\ Aristotle University of Thessaloniki \\ abouroutis@gmail.com
}

Over time, the monasteries of Mount Athos became owners of great estates in the Balkan Peninsula. These metochia contributed significantly to the monasteries' resilience. Vatopedi acquired the Souflar çiftlik in 1907 in order to pursue its goals of selfsufficiency and sustainability. The article reveals important details about the operation of Souflar Metochi and its impact on the local and the monastic economy. The detailed procedures followed by the monks appointed to manage it are a valuable source of information concerning the agricultural methods employed, the weights and measures used and the forms of labour relations of the local population.

Keywords: Vatopedi Monastery; metochia; dependent peasants; monastic agriculture; monastic economy

\section{Introduction}

For centuries the monasteries of Mount Athos owned land in the Balkans. Preserving the unique character of Orthodox monasticism, the Athonite monasteries survived the decline of the Byzantine Empire and would also outlive Ottoman rule. Halkidiki was the main region where the monasteries managed to keep their land after losing much of their holdings in the rest of the Balkans (for example, in the Danubian Principalities

1 The research for this article was supported by the Network Dedicated to the History of the Monastic Economy, hosted by the Centre of Advanced Study Sofia and the Center for Governance and Culture in Europe (GCE), in the School of Humanities and Social Sciences, University of St Gallen as part of the project 'Does Monastic Economy Matter? Religious Patterns of Economic Behaviour'. I thank the reviewers and the Editor for their thoughtful comments and remarks towards improving my manuscript and also Professor P. Kotzageorgis and Dr I. Papangelos for their valuable comments and suggestions.

(C) The Author(s), 2021. Published by Cambridge University Press on behalf of Byzantine and Modern Greek Studies. This is an Open Access article, distributed under the terms of the Creative Commons Attribution licence (http:// creativecommons.org/licenses/by/4.0/), which permits unrestricted re-use, distribution, and reproduction in any medium, provided the original work is properly cited.

DOI: $10.1017 /$ byz.2020.23 
and Bessarabia) by the second half of the nineteenth century. ${ }^{2}$ Halkidiki's proximity to the monastic community, as well as its rich hinterland, made it an ideal location for the monasteries to establish great agricultural estates known as metochia, which demonstrated resilience and sustainability over time.

The metochia were a vital source of supplies for the monasteries and their numerous dependencies (sketes, kellia, konaks). Furthermore, they triggered economic and commercial activities as early as the later Byzantine period (tenth to fifteenth centuries), and up to the early twentieth century. It has been estimated that more than forty per cent of the total land area of Halkidiki belonged at one point to the Athonite monasteries. ${ }^{3}$ Most authorities have considered that monastic possessions and landownership in Halkidiki in the modern era had their origins in the Byzantine period and survived, despite some serious losses, the Ottoman period. ${ }^{4}$ However, one of the largest agricultural estates, Souflar Metochi, was acquired as late as in the early twentieth century. The metoch $i$ was situated in the area where the Byzantine village of

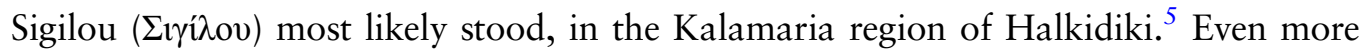
surprisingly, the Athonite Monastery of Vatopedi acquired the large estate from the Modianos, an old Jewish family from Thessaloniki, ${ }^{6}$ who, it would appear, had owned it for almost thirty-five years. ${ }^{7}$

Although Vatopedi ranks second in the monastic hierarchy and was considered among the most important and wealthy communities in Mount Athos, its metochia did not guarantee the desired levels of self-sufficiency. On the eve of the twentieth century, Vatopedi held certain metochia in Halkidiki. The first, Agios Mamas, bearing the name of the small village nearby, was located on the Toronean Gulf, between the Kassandra and Sithonia peninsulas. A 1301 chrysobull issued by Emperor Andronikos

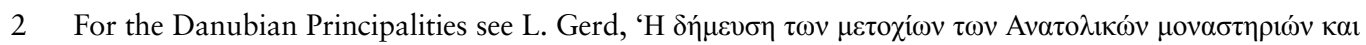

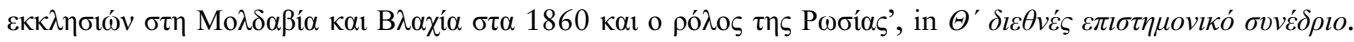

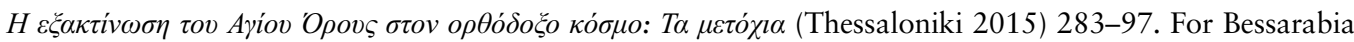
see L. Gerd, Russian Policy in the Orthodox East: The Patriarchate of Constantinople (1878-1914) (Berlin 2014) 64-5.

3 B. C. Gounaris, 'Introduction', in B. C. Gounaris (ed.), Mines, Olives and Monasteries: aspects of Halkidiki's environmental history (Thessaloniki 2015) 20.

4 A. Harvey, 'The monastic economy and imperial patronage from the tenth to the twelfth century', in A. Bryer and M. Cunningham (eds), Mount Athos and Byzantine Monasticism (Aldershot 1996) 90.

5 For Sigilou village, which some sources claim to have existed till the sixteenth century, see E. Kolovos,

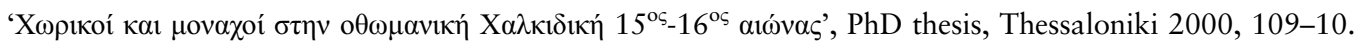
The name 'Souflar' derives from the Turkish word sofu meaning ascetic. For the Kalamaria region of

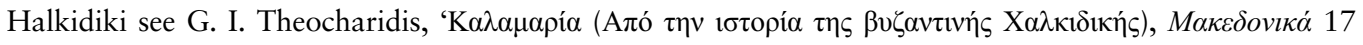
(1977) 262-8

6 J. Nehama, Histoire des Israélites de Salonique (Thessaloniki 1978) 1513-17, and M. Mazower, Salonica, City of Ghosts (London 2004) 231, 237. The Modianos, along with the Allatinis, were among the wealthiest families, not only in Thessaloniki, but in the Ottoman Empire.

7 Holy Vatopedi Monastery (hereafter HVM), 29091, Kallistos Vatopedinos, Codex of Souflar (1911). 
II Palaiologos mentions that Vatopedi had a metochi in the area. ${ }^{8}$ Its holding was confirmed in 1329 by Andronikos III, who issued a new chrysobull, and in 1346 by the Serbian King Stefan Dušan, during his short-lived reign over Halkidiki; he also donated part of the Agios Mamas settlement to the monastery. For this reason the Christian residents of the settlement were attached to the metochi and laboured there as paroikoi (dependent peasants). ${ }^{9}$

Ormylia, some twenty kilometres from Agios Mamas, was the location of another metochi. Next to it, Vatopedi owned another estate, Agios Fokas. These two metochia lacked sufficient cultivable land - Agios Fokas was mainly forest and pasture - and were used for winter grazing for the monastery's flocks of sheep. ${ }^{10}$

Closer to Mount Athos, Vatopedi owned a few more metochia. Prosforion, or Pyrgos, named after the big Athonite-style tower that still stands there, was situated where the modern town of Ouranoupoli is now located and where boats for Mount Athos depart. Another metochi, established in the early fourteenth century, existed on the little island of Ammouliani in the Athos Gulf and was mainly used for pasture. On the eve of the twentieth century the monks expanded an olive grove to support Vatopedi's oil needs. ${ }^{11}$ Finally, Vatopedi had since the twelfth century, owned another metochi, Provlakas, in the outer part of the Athonite peninsula, close to the Xerxes canal ${ }^{12}$ and near present-day Nea Roda.

However, Vatopedi's annual consumption needs in the early twentieth century far exceeded the total production of its metochia. Furthermore, the fragmented location of its metochia presented an extra logistical burden in terms of production, transportation and labour costs. It would appear that Vatopedi had to source

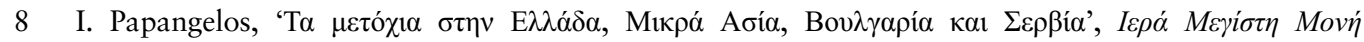

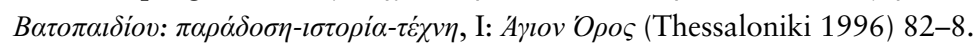

9 K. Smyrlis, “'Our lord and father”: peasants and monks in mid-fourteenth-century Macedonia', Travaux et Mémoires 16 (2010) 787. After the acquisition of Souflar Metochi, the Agios Mamas metochi served as a subsidiary of the former. In many cases Souflar would provide animals and farming equipment to the appointed supervising monk of Agios Mamas and the latter would support Souflar's total output of foodstuffs. HVM, 29043, Letter from HVM to Souflar, 31 May 1922. In the letter the appointed monks of Souflar were ordered to send five or six of the oldest oxen to Agios Mamas to be used in light work on the threshing floor.

10 Papangelos, ‘T $\alpha \mu \varepsilon \tau o ́ \chi 1 \alpha ~ \sigma \tau \eta v$ E $\lambda \lambda \alpha \alpha \delta \alpha$ ', 84-5. In 1903, a Greek banker, Dimosthenis Angelakis, proposed to the monks that they deforest the area for charcoal production. This method had been in use, especially since the eighteenth century, to meet increasing demand for charcoal. For the deforestation process, see E. Kolovos and Ph. Kotzageorgis, 'Halkidiki in the early modern period: towards an environmental history', in Gounaris (ed.), Mines, Olives and Monasteries, 161. For Angelakis' proposal see HVM, 307, Letter from D. Angelakis to HVM, Thessaloniki, 18 February 1903. Angelakis proposed that the deforestation should be carried out in two metochia: in Ormylia and on the islet of Ammouliani. Had the monks accepted Angelakis' proposal, they would have greatly expanded their cultivable land. Vatopedi opted not to follow Angelakis' advice, thus preserving the area's ecosystem.

11 Papangelos, 'T $\alpha \mu \varepsilon \tau o ́ \chi 1 \alpha \sigma \tau \eta v$ E $\lambda \lambda \alpha \dot{\alpha} \delta \alpha$ ', 83-4.

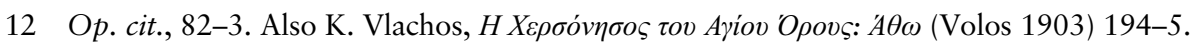


additional quantities from the local market in Thessaloniki and surrounding areas in order to cover its annual needs, a costly endeavour that offered no guarantee in terms of quality. In October 1904, the Bank of Mytilene in Thessaloniki purchased, on behalf of the monastery, 24,620 okas of barley (an oka was equal to 400 Ottoman dirhems or $1.282 \mathrm{~kg}$ in the Greek case). ${ }^{13}$ The monastery covered the cost of transportation and had to pay the bank a commission of one per cent for its services. However, as the quality of the purchased barley was lower than expected, the monks complained to the bank. The bank claimed that better-quality barley was much more expensive because wholesalers were speculating on the price. ${ }^{14}$

Since its main goal was self-sufficiency in cereals and crops, Vatopedi had to find a sustainable and permanent solution. The acquisition of the Souflar estate at last enabled the monastery to support itself and its dependencies. With this in mind, the aim of the present article is to present the multifaceted activity of an Athonite metochi in the Halkidiki area. It argues that the metochi was beneficial not only for the monastery itself but for the local regional economy, since it involved dependent peasants and neighbouring settlements, in its activities. ${ }^{15}$ The Souflar operation, which ran from 1907 until 1924 when the monastery ceded it to the Greek state, reveals interesting details about labour relations. It operated in a period marked by political and social changes and exemplifies how tensions between the monks and the laity increased, undermining the old system of dependent peasants. In addition, we can identify the different perceptions of the monks who lived in the secluded religious environment of Athos and those sent out to manage the metochi, living in rural areas of Halkidiki and mainly socializing with lay people. Souflar was the key to a sustainable solution. In the hands of Vatopedi and the monks appointed to manage it, Souflar would become a bourgeoning economic hub for the local region, a cluster and driving force for numerous agricultural activities that interacted with all the communities of the area.

\section{Souflar Metochi}

Although the sale contract between Vatopedi and the Modiano family was sealed in 1905, the final agreement was not signed until 1907, having taken almost two years to complete. The reason for the delay was that the Modianos had subleased some of the estate, probably the most fertile part, to a Greek Orthodox Christian, Spyridon Dimitriou. Consequently, the monastery had to proceed with a thorough inventory and a separate agreement with Dimitriou in Souflar, where, among others, it purchased some necessary farming equipment and tools. ${ }^{16}$ The Vatopedi monks were

13 HVM, 129, Invoice from Bank of Mytilene to HVM, Thessaloniki, 9 October 1904.

14 HVM, 138, Bank of Mytilene to HVM, Thessaloniki, 2 November 1904.

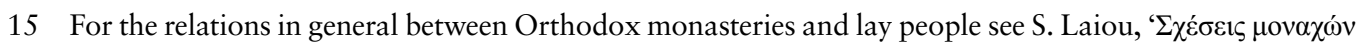

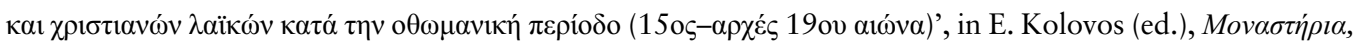

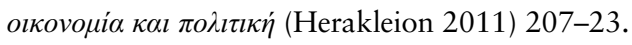

16 HVM, 127050, Catalogue of purchased goods. 
quite careful and cautious about their investment. Performing due diligence, they translated all the deeds $(t a p u)$ from the Ottoman cadastre into Greek. As the Souflar çiftlik was fragmented, so too were its entries in the Ottoman land registers. The estate comprised around ninety-five entries in the Ottoman cadastre (land, houses, warehouses, etc.), which offered a detailed analysis of each property, including the type of land or building, its dimensions and its location. ${ }^{17}$ In order to seal the contract in 1905 and for it to be fully legal, the Ottoman authorities conducted a sinurlama ('delimitation'), which involved Ottoman public servants and notables from neighbouring settlements defining the boundaries of the estate on the spot. ${ }^{18}$

Concerning the labour relations and the working conditions in Souflar in general, the contract reveals an interesting issue: Vatopedi had to pay and assume the debts of the twenty-one geratzides ( $\gamma \varepsilon \rho \alpha \tau \zeta \bar{\eta} \delta \varepsilon \varsigma$ ), the Christian dependent peasants who lived on the çiftlik with their families. ${ }^{19}$ The geratzides, who cultivated specific plots in Souflar for their own benefit and used the equipment and the common facilities, purchased the necessary seed on credit from the çiftlik owner, and paid him back by handing over a specific percentage of their total crop. Their working status equated to that of agrarian

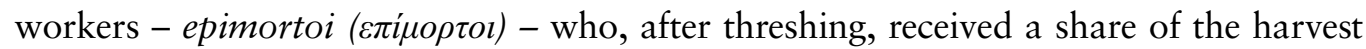
depending on the agreement. In some cases, they are referred in general as misareoi ( $\mu \iota \sigma \alpha \rho \varepsilon o \iota)$, which is related to another term widely used in the Greek lands,

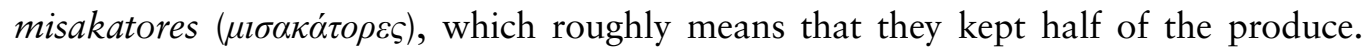
Along with the geratzides, a few dependent peasants referred to in the Vatopedi

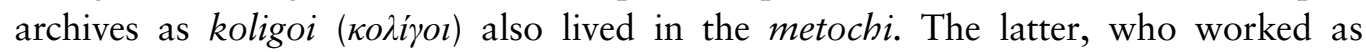
sharecroppers or carried various auxiliary tasks, constituted a secondary labour force, with even fewer privileges and a smaller share of the produce. As early as the 1880s, observers had noted the long-term presence of Christian dependent peasants and their attachment to Souflar. ${ }^{20}$ There are no details as to how some of the farmers ended up as geratzides and others as koligoi, but one may speculate that the former had a long attachment to the çiftlik while the latter were on the whole newcomers.

The provision in the agreement concerning the geratzides meant in practice that the transfer of ownership also included the manpower of the property, along with their outstanding debts. As it appears, the geratzides acknowledged, through signed

17 HVM, 127102, catalogue of Souflar properties (tapu). For each property, a brief description in Greek was given with the number of the tapu, Ottoman [Hijra] year, location of the land (e.g. 'Soulou Tarla') and the borders or the neighbouring properties (e.g. Housein, Emin Aga, rural road, etc.). It is quite interesting that some of the buildings, like the barns or the houses where the dependent peasants of the çiftlik lived, were characterised as miri [public land] and others as mülk, meaning that full private property (freehold) was acknowledged.

18 HVM, Sinırlama, 8.3.1323/1905. The whole procedure was very thorough, recording details about the boundaries of the estate and specific landmarks.

19 HVM, 127065-75, Souflar Metochi inventory, 15 September 1907. In the inventory, the geratzides' debt is found in section C. The term geratzides derives from the Turkish word kiract and means 'tenant farmers'.

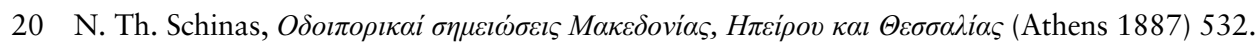




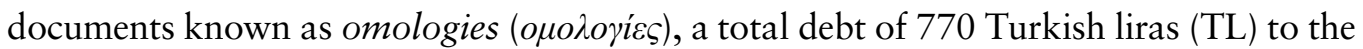
previous owner. This debt was placed at the disposal of Souflar's new proprietor. ${ }^{21}$

Purchasing such a large estate as Souflar was a big investment even for a monastery of the calibre of Vatopedi. For this reason, and for the successful valuation of the çiftlik, a report, possibly written by a monk, briefly outlined the prospective acquisition. ${ }^{22}$ As already mentioned, according to official titles in the Ottoman cadastre (tapu), the property amounted to 11,200 stremmata (Ottoman dönüm: 1,200 hectares). However, the original property, as stated in the report, was over 15,000 stremmata (1,500 hectares). ${ }^{23}$ This discrepancy should come as no surprise, since variance between the official and the actual size of land was common and was often an issue of dispute. Consequently, there were different figures concerning Ottoman land ownership in the area adjacent to Souflar, where Muslim settlements existed: the report mentioned that the Muslims claimed to possess 950 stremmata (95 hectares) whereas according to the Ottoman registers they held 767 stremmata (about 77 hectares). ${ }^{24}$

From the details of the exploitation of the metochi over the years, it is obvious that the monastery cultivated only part of the acquired land. More specifically, the agricultural production statement for 1922-3, compiled for tax purposes, states that the geratzides cultivated 549 stremmata and the monastery itself $450 .{ }^{25}$ That gives a total of 999 stremmata (almost 100 hectares), that is, less than ten per cent of the total land of the metochi. However, the monks employed another form of cooperation with some neighbouring Muslim settlements; was an interesting development, as the vast majority of the rural population in the area was Christian. In the correspondence between Vatopedi and Souflar, the neighbouring Muslim villagers are referred to in some documents as Yürüks and in others as Turks. ${ }^{26}$ The Yürüks were a nomadic population engaged in long-distance transhumance who were introduced by the Ottomans to the wider Thessaloniki area in the late fourteenth century. ${ }^{27}$ After the sixteenth century they gradually adapted agricultural practices and settled in

\section{HVM, 127075.}

22 HVM, 127077-8, Report for Souflar Metochi.

23 Op. cit.

24 HVM, Draft of Muslim ownership in the Souflar area. There are five owners mentioned, who must broadly correspond to the respective Muslim settlements in the area: Moula Effendi, Moula Emin Kara Tepe, Memet Tsalmaz, Hussein Arnaout, and Hussein Tsaous and his brothers.

25 HVM, 29189, Souflar annual production statement 1922-3.

26 HVM, 29040, Letter from HVM to Souflar Metochi, 12 July 1922. In the letter the monks appointed to manage Souflar are instructed to purchase supplementary quantities of wheat from the neighbouring Turkish settlements.

27 For the settlement of the Yürüks in Halkidiki, see Kolovos and Kotzageorgis, 'Halkidiki in the early modern period', 128-9, 139. Interestingly, there are records of agreements between Yürüks and Athonite monasteries dating back to the end of the sixteenth century, when Agios Pavlos Monastery allowed nearby settled Yürüks to use the monastic land for pasture for an annual fee. Op. cit, 144. See also P Kotzageorgis, 'Nomads (yürüks) and environment in Early Modern Halkidiki, Balkan Studies 50 (2015) 95-118. 
Halkidiki's rich hinterland, which is how they ended up so close to Souflar. The available sources do not reveal if there was an already existing relationship with the previous owners, but the monastic archives indicate that the new owners maintained a steady

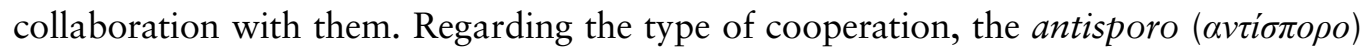
method was applied. ${ }^{28}$ Under that system, the land located on the boundaries of the metoch $i$ was tenanted in lieu of a share of the grain production (wheat, barley, oats). ${ }^{29}$ Therefore, to the aforementioned 999 stremmata figure must be added another 458 stremmata of wheat, oat and barley that were cultivated by the villagers of the neighbouring Muslim settlements. ${ }^{30}$ But even when this land is included, the total arable land still falls short of the total acreage of the metochi. Although this article cannot engage in hypotheses about the possible reasons for this discrepancy, we should point out that the monastery found other means to exploit the neglected land. For instance, in Souflar there was plenty of water for irrigation, allowing the maintenance of a great vegetable garden (bostan) under tenancy and a water tank at an estimated value of eighty TL. ${ }^{31}$ Furthermore, in order to maximize its investment, Vatopedi leased the existing caravanserai in the central buildings compound of the metochi and part of the seafront warehouse and offered its non-cultivated land, including forest, for pasture for both seasons (winter and summer) to third parties under a respective agreement. ${ }^{32}$

From the moment Souflar was acquired, the monastery and the supervising monks regularly communicated in writing. In order to have a complete overview of operations and to work the estate to its maximum potential, every year or two the monastery

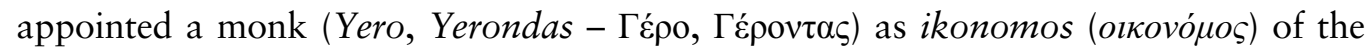
estate. He was responsible for the whole operation, the economic transactions and liaisons with third parties, and labour agreements with the workforce (geratzides, koligoi, seasonal workers and auxiliary personnel) of the metochi. The ikonomos was required to furnish detailed reports every two or three months on the sowing, cultivation and threshing of all grains (wheat, oat, barley) and other commodities (onions, tobacco, etc.). An annual inventory and report on the performance of the metochi provided Vatopedi with a detailed picture, thus enabling it to plan for any necessary changes.

Since the whole operation required serious logistic capabilities and management skills on the part of the ikonomos, the monastery appointed another monk as assistant

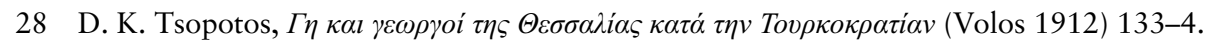

29 In some cases, the distant land was the subject of ownership disputes and the antisporo method could

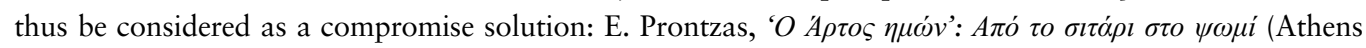
1994) 263.

30 HVM, 29158, Souflar annual production report 1921-2.

31 HVM, 127077.

32 In 1922-3 the caravanserai, the house and the stable next to it were rented by Konstantinos Bouchakis from the village of Vavdos. From grazing, the monastery, among other things, secured every year some hundreds of okas of cheese and butter. 


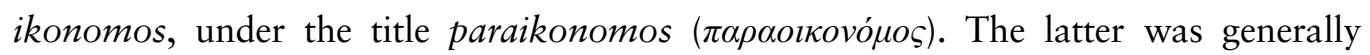
entrusted with day-to-day operations, while the ikonomos, was responsible for all financial aspects as well as interaction with the peasant farmers and the monastery itself.

The most difficult period in the operation of the metochi was harvest time. The ikonomos and paraikonomos had to oversee the dispatch of the koligoi and the seasonal workers to the field, as well as the animals and threshers, the transfer of the crop to the warehouses and its subsequent weighing, and the final evaluation of the whole operation. Furthermore, both monks had to supervise the allocation of the proper quantities by the geratzides and the nearby settlements after threshing and to confirm that they had delivered the agreed percentages. When the crop exceeded the anticipated needs of the monastery, the surplus was sold to cover the expenses and the maintenance of the metochi as well as state taxes. When the crop was moderate and production insufficient for the monastery's needs, the ikonomos was assigned to make up the shortfall. ${ }^{33}$ In most cases, the ikonomos would purchase from the geratzides or the Muslim settlements a share of their crops.

Acknowledging the difficulties over the years during the harvest period, the monastery decided to appoint a monk as harvest supervisor. Called the esodiastis

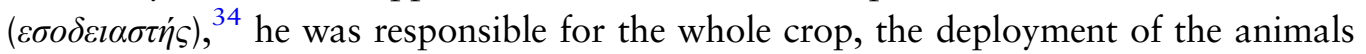
(oxen) and threshers, as well as the teams of workers under a particular labour agreement with the metochi.

As already pointed out, Souflar was the main source of supplies for Vatopedi. The most productive years of the metochi were in the final five years of its operations, from 1919 to 1924. In 1920, Vatopedi made an important change: for time management and better coordination in the allocation of animals and manpower, it divided the arable land of the metochi into two parts, an upper and a lower. ${ }^{35}$ The long-term aim was to increase production and expand the amount of arable land by new means (equipment and threshing machines) and by constructing new buildings (warehouses, stables). As the annual inventories make clear, every year the monastery proceeded to make changes and invest in order to increase productivity. More specifically, the 1923-4 inventory includes, among other things, three threshing machines, two (old) harvesters, two ploughing machines, one ear collector, five carts, one flour mill and a complete oil mill. ${ }^{36}$

The metochi cultivated wheat, oat, barley, corn, chickpeas, fava beans, onions, tobacco and vetch, the last of which was used primarily for animal fodder. Moreover, the estate also contained around 1800 olive trees which, through an agreement with

33 HVM, 29090, Letter from Souflar Metochi to HVM, 21 July 1922. The ikonomos bought 10,000 okas of wheat to be added to the metochi's wheat production.

34 HVM, 29038, Letter from HVM to Souflar Metochi, 9 April 1922.

35 HVM, 29058, Letter from HVM to Souflar Metochi, 22 July 1920.

36 HVM, 29102. The inventory records that the oil mill contains an olive crusher, an olive press and two boilers. 
two local farmers, undertook their cultivation and harvest for a share $(45 \%)$, provided the monastery with a few thousand okas of olive oil. ${ }^{37}$ Maximizing the exploitation of production, the by-product of the olive oil extraction was used to make soap. ${ }^{38}$ Similarly, the olive pomace was sold every year for a small profit. ${ }^{39}$

\section{Weights and measures}

At this point, it is necessary to comment on the weights and measures used by Souflar Metochi for its foodstuffs. The most common and traditional unit of weight was the

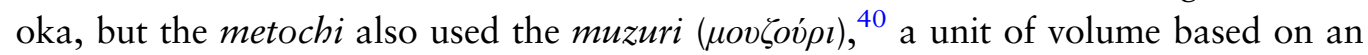
earlier measure of dry capacity. The origin of the word muzuri is not entirely clear: it may derived from Latin missorium or Italian/Venetian misuralmesura. The term had been employed in Crete and the Cyclades since the period of Frankish rule. The muzuri was not widely used on the Greek mainland, but in Halkidiki and the Mount Athos monasteries, including Vatopedi, it features in most references in the Athonite documents and tables as the main unit of volume. ${ }^{41}$ The muzuri was widely used by the monks in all accounts and estimates and for the final output of the production. In official tables and registers, the monks always provided equivalent figures in okas. In the agreement between Vatopedi and the Muslim villages around Souflar, namely Bozala, Bayraklı and Pazarlı mahalles, another rare unit of measurement was used, the koutlo. $^{42}$ As mentioned already, in its business relations with the Ottomans, the metochi applied the antisporo method, where it granted specific land close to neighbouring settlements for a return of one to one and a half koutlo per stremma. ${ }^{43}$ Although the agreement with the Muslim villagers was made in koutlo, the production and the share received by the appointed monks was always measured in muzuria. In the bibliography, the muzuri varies greatly in value depending in the commodity and the area in question. ${ }^{44}$ In Souflar, we can establish the exact equivalence in okas,

37 The tenants of the olive grove, Vasilios Papas and Christos Kakarikas, used the metochi's oil mill, and Vatopedi had to provide them with all the necessary facilities (housing, firewood and carts).

38 HVM, Letter from HVM to Souflar Metochi, 23 July 1922. As mentioned, in the event that the leftovers of the oil were not already used to create soap, the monastery requested 600 okas for its own needs.

39390 drachmas in 1922. HVM, Souflar Metochi cashbook for 1922-3, subcategory 'various sales'.

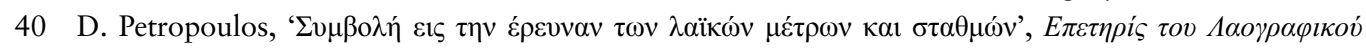
Apxíov 7 (1952) 62, 68-9.

41 The muzur was used as a value in Mount Athos for centuries: A. Fotić, 'Kassandra in the Ottoman documents from Chilandar (Hilandar) Monastery (Mount Athos) in the sixteenth and seventeenth centuries', Balcanica 40 (2009) 62-3, 65.

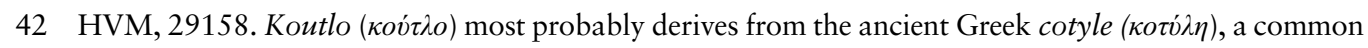

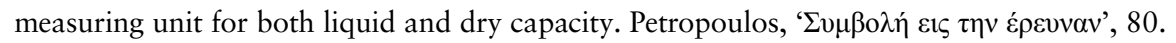

43 According to Papangelos, one koutlo was equal to a quarter of a muzuri. According to his calculations, one muzuri was equal to fifty okas; thus one koutlo was equal to twelve and a half okas. In Souflar's case there is a small difference. I. Papangelos, 'O A $А \tau o \varsigma \eta \mu \omega ́ v ', 218$.

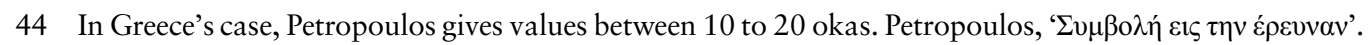


depending on the cereal, on the basis of the calculations the monks made themselves, which is very helpful in establishing the differences. For wheat, one muzuri equalled fifty-two okas of newly produced wheat and forty-eight okas of wheat from the previous year's harvest; for barley and oats, one muzuri was equal to thirty-nine and thirty-five okas respectively. ${ }^{45}$ Considering the antisporo received by the Muslim settlements and the fact that one koutlo was equal to a quarter of a muzuri, we can safely estimate that one koutlo was equal to thirteen okas, which is confirmed by the figures of the Souflar monks themselves.

The contribution and the involvement of all partners in the metochi's output are demonstrated in the overall production figures for 1921-2. The totals for wheat, barley and oats are based on the performance of the metochi's arable land, the share received by the geratzides and by the Muslim settlements in the wider Souflar area. The total wheat output was 388 muzuria, with 110 muzuria coming from the metochi's moderate crop, 166.5 muzuria from the geratzides and 111.5 muzuria from the Muslim villages. ${ }^{46}$ Of the barley output, 115.5 muzuria came from the metochi's own production, 66.5 from the geratzides and 14 from the Muslim settlements, amounting to a total of 196 muzuria. ${ }^{47}$

Concerning the geratzides, in 1921-2 eleven of them appear in the registers, meaning there was a serious reduction in their number, since twenty-one were recorded in the agreement with Vatopedi in 1905. It is not clear whether some of the geratzides had left the metochi altogether or had been downgraded in its labour hierarchy to the status of koligoi. The names of the geratzides - Vasilios Papas, Nikolaos Maniatis, Georgios Lambrou, Stergianni Ioannou Palioka (widow), Nikolaos Kalaboukas, Christos Kakarikas, Christos Matzaris, the widow of Georgios Zagliverinos, Vasilios Mersinas, Georgios Tzouras and Anagnostis Paliokas - show they were all Greek Christians. ${ }^{48}$ Some of them had quite considerable production output, such as 168 muzuria in Papas' case or 244 muzuria in Kakarikas' case, while Matzaras had only 39 muzuria. Some others, for reasons not explained, barely produced the amount of seed they had sown. ${ }^{49}$ Thus, there was inequality among the group of geratzides, some of whom cultivated more land than the others.

For the second category of dependent farmers (epimortoi), the koligoi, the archives yield little information except that they were few in number and were mainly used in auxiliary works and cultivation. Thus, the geratzides formed the bulk of Souflar's labour force.

46 Op. cit.

47 Op. cit.

48 Op.cit.

49 For instance, Kakarikas, after subtracting the cultivated seeds, had 112 muzuria of wheat, of which Vatopedi received a share of 45 muzuria, 22 muzuria of barley with 9 for Vatopedi and 110 muzuria of wheat with share $363 / 4$ muzuria for the monastery. 
Further details were also given in the annual reports so that Vatopedi could evaluate the contribution of each of the neighbouring villages to the metochi's output. According to this information, the metochi received 44 muzuria of wheat from 140 stremmata in Bozala, 58 muzuria from 172 stremmata in Bayrakl1, and 9.5 muzuria from 30 stremmata in Pazarl. ${ }^{50}$ In practical terms, the Muslim villagers contributed close to 5,800 okas of wheat to the metochi.

As regards olive oil production, according to the agreement with the two Christian peasants, the metochi received $55 \%$ of the total output. In 1921-2, which appears to have been an excellent agricultural year for olive oil production, it received 5,080 okas, close to 7 tons.

\section{Labour relations}

When it comes to labour relations between the geratzides and the monastery, it was the latter which provided the land, seed, housing and animals, as well as the threshing equipment, and the geratzides had to repay roughly $40 \%$ of their total crop in wheat and oats and one-third in barley. ${ }^{51}$ In times of bad harvest or unexpected events, the ikonomos, after informing the monastery, agreed to negotiate and even waive the agreed percentage. For instance, in 1922 Anagnostis, a geratzis, was enlisted in the Greek Army and consequently the harvest barely yielded the quantity of seed used. ${ }^{52}$ For this reason the monastery did not ask for the payment of his share.

Naturally, as in any other enterprise, the ikonomos often had to strike a balance between the existing agreement with the geratzides and the inability or the unwillingness of the latter to fulfil their obligations to the monastery. Thus, from as early as1907, when the monastery became the owner of Souflar, to 1924, just before it conceded it to the Greek state, the monks had to deal with certain problems. In 1908, a moderate year in terms of crop yields, the geratzides refused to hand over their agreed share. In order to resolve the problem, the monastery called on its monks in Souflar not to engage in any confrontation with the sharecroppers but, 'with good manners, prudence and avoiding any other extreme measure', to secure at least part of the debt or to exchange the existing omologies with updated ones. ${ }^{53}$ In 1921, Vatopedi agreed to the geratzides' request to repair their houses and the stables they used, since they were the property of the monastery, and instructed the ikonomos, Grigentios Vatopedinos, to hire two skilled workers for this task. ${ }^{54}$ The same letter

50 Op. cit. Muslim settlements production and monastery's share. Smaller quantities were also registered for barley and oats.

51 From the gross harvest, the quantity of seeds used was subtracted and a share, varying from thirty-five to forty per cent, was accounted on behalf of the monastery.

52 Op.cit.

53 HVM, 29001, Letter from HVM to Souflar Metochi, 24 July 1908. Furthermore, the monastery called on the monks in Souflar to secure the receipt of the seeds as also of the keys and locks of the warehouses and of the rest of the buildings in the metochi.

54 HVM, 29021. Letter from HVM to Souflar Metochi, 18 November 1921. 
called for a de-escalation of tensions between the two sides, since the geratzides had reiterated their promise to comply with their obligation and to pay back the outstanding share of maize and sesame. For this reason Vatopedi authorized Grigentios to withdraw the lawsuit he had filed against the geratzides. Requesting the support of the civil authorities was nothing new for the Athonite monasteries in the serious disputes they had with the dependent peasants and their labour obligations in Halkidiki. Written sources from as early as 1358 show that Vatopedi requested the intervention of Thessaloniki's governor concerning the debt of the dependent peasants of the Agios Mamas metochi. ${ }^{55}$ A similar situation arose in 1924 when the monks, after the geratzides had again failed to hand over the agreed quantity of seed, received instructions from the monastery to secure either part of it or its equivalent value. Vatopedi had already anticipated this development and ordered the monks to seek, if necessary, the intervention of the authorities, administrative or judicial. ${ }^{56}$ Constant disagreement seems to have been part and parcel of metochi life, and the monks had to strike a balance between the needs of the monastery and the reality that the geratzides were not always willing to abide by their agreements.

Vatopedi did not rely solely on Greek geratzides and koligoi. At certain times of the year, such as harvest, local seasonal workers would be hired for a wage. In 1923, a team of gypsy Muslim peasants from neighbouring Bozala, under their foreman Sysli Ramadan, was contracted for the harvest. ${ }^{57}$ The same applied to various positions, such as in the warehouses and guarding land. The metochi engineer was a Greek Christian, mastro-Nikolas, the coppersmith a Muslim gypsy, Mehmet Moundouris. ${ }^{58}$

It is important, however, to highlight the different perceptions between the lay and the monastic world concerning labour relations. As they lived in seclusion from the real world, the monks in Vatopedi were not in a position to identify the rapid social changes that were in train, whereas the monks appointed to manage Souflar found themselves in the midst of them. When in summer 1922 the few koligoi demanded to work for a wage instead of the old system of receiving a percentage of the crop, the paraikonomos, noting the difficulties and the anxiety of the ikonomos in finding a solution, suggested that this would probably be beneficial for Vatopedi as well. ${ }^{59}$ This was a new and rather provocative point of view, considering that the Orthodox monasteries had relied on the dependent peasant system for centuries and were extremely wary of innovations, especially with regard to labour relations. However, the paraikonomos had a good reason to support the new idea: citing the example of the neighbouring metochi of Zografou Monastery, Evgenios Vatopedinos claimed that

56 HVM, 29003, Letter from HVM to Souflar Metochi, Vatopedi, 11 August 1924.

57 HVM, 29132, Agreement between ikonomos Paisios Vatopedinos and Sysli Ramadan (no date).

58 HVM, 29078, Letter from Germanos Vatopedinos to Charitonas Vatopedinos in Thessaloniki, 12 September 1909.

59 HVM, 29090, Letter from paraikonomos Evgenios Vatopedinos to HVM, 21 July 1922. 
the ikonomos there paid 14,240 drachmas in wages to the croppers for a total production of 2,365 muzuria. On the contrary, for a crop of 1,298 muzuria the Souflar ikonomos gave a share of 180 muzuria (9,360 okas) to the koligoi, which amounted to 28,080 drachmas. In practical terms, Vatopedi paid almost double for half of the crop. A rapid solution was needed: the metoch $i$ was in the middle of the harvest. The monastery agreed that waged personnel needed to be contracted immediately, but also pointed out that the koligoi enjoyed free accommodation in the houses of the metochi. If they sought a new labour relationship they could no longer expect free housing. Thus Evgenios was instructed to persuade the peasants to work under the old system. If they insisted on wages, then they would have to vacate their metochi homes so that new peasants from the area could be recruited as koligoi to replace them. ${ }^{60}$

In another case, in 1924, the Souflar ikonomos faced a problem with two koligoi: one had died, and the other had enlisted in the Greek army. Vatopedi proposed two solutions: either the ikonomos and paraikonomos would have to assume the burden of the cost of the two koligoi by hiring the necessary number of peasants to do the harvest and the threshing of their share, or the rest of the koligoi would have to follow the same procedure. Depending on the total output, they would keep the customary share. ${ }^{61}$

\section{Harvest and outcomes}

When it came to cultivation, threshing and total output, the period up to mid-August each year was crucial, since it included the harvest and the general evaluation of the operation of the metochi. By the beginning of July, communications between the metochi and Vatopedi increased in anticipation of the reception of the goods. The monastery had already estimated its annual consumption needs as well as its fodder requirements, and the metochi adjusted the necessary quantities for shipment. As mentioned, in the event of a bad or a moderate crop, the metochi had to source and buy supplies elsewhere in order to reach the desired amounts.

Transporting the goods to the monastery was a challenge: paved roads were few and in poor condition, with the usual river floods in Halkidiki creating great obstacles. On the other hand, delivering some thousands of okas of wheat, oat and barley would require hundreds of mules and carts. Since the metochi had access to the sea, the harvest was loaded onto boats - possibly by means of a wooden dock - and transported to Vatopedi. In August 1920, for instance, the ikonomos, Yero-Iosafat Vatopedinos, sent the monastery, with the vessel Katerina under Captain Evangelos Stoungos, from Litochoro, Pieria, around 52,000 okas $(66,418 \mathrm{~kg})$ of cereal $(38,640$ okas of wheat and 13,168 okas of barley) and approximately 900 okas of canned cheese. ${ }^{62}$ In just

60 HVM, 29028 Letter from HVM to Souflar Metochi 29 July 1922.

61 HVM, 29007 Letter from HVM to Souflar Metochi, 19 May 1924.

62 HVM, 29085 Letter from ikonomos Iosafat Vatopedinos to HVM, 8 August 1920. 
one shipment, Souflar dispatched to Vatopedi more than sixty-seven tons of foodstuffs. The same means of transportation were basically used on all occasions. Following the 1923 harvest, the ikonomos, Yero-Paisios Vatopedinos, made two shipments to Vatopedi. The first shipment, on the sailboat of Captain Karponis in mid-July, contained 27,808 okas of wheat, while the second, on 1 August with Captain Mairis, comprised 19,168 okas of wheat, 30,000 okas of barley and 386 okas of onions. ${ }^{63}$ In summer 1923, Vatopedi received two shipments from Souflar, containing 77,362 okas $(99,178 \mathrm{~kg})$ - close to 100 tons of foodstuffs - in total.

\section{Political developments in Greece}

However, this economic microcosm could not remain untouched by greater events. The political vicissitudes in Greece, and the Balkans in general, in the early twentieth century dramatically changed the situation. After the First World War, in 1919, the Allies gave Greece the green light to intervene on the other side of the Aegean, in Asia Minor. The occupation of Smyrna, a port-city of great economic significance with a Greek majority, together with its hinterland, was the realization of the old Megali Idea (Great Idea). ${ }^{64}$ However, this ambition ended dramatically in 1922 with the Asia Minor Disaster and the exodus of hundreds of thousands of Greeks. The end of the ancient Greek presence in Asia Minor was sealed in 1923 by the Lausanne Treaty and the population exchange between Greece and the newly born Republic of Turkey. ${ }^{65}$

The arrival from 1922 of thousands of refugees from Asia Minor in Greece, and especially its northern territories, pushed the state to take action in the face of a humanitarian crisis. The monastic estates in Halkidiki presented a solution for the resettlement of the refugees. The Vatopedi monks were anxious about this development, since groups of refugees were settled nearby. With little support from the state, the refugees' situation was miserable. In a letter to Vatopedi in June 1923, the ikonomos Paisios Vatopedinos informed his brothers that the authorities had confiscated half of the crop from the nearby Muslim settlements for use by the refugees. ${ }^{66}$ A month later, Paisios informed the monastery that the construction of a refugee settlement was proceeding. Although there is no evidence that this took place on the monastery's property, Souflar's status was clearly in question, which may explain why the geratzides were negatively disposed towards the monks and seized the opportunity not to fulfil their obligations. ${ }^{67}$ Furthermore, some refugees had trespassed on Athonite properties to cultivate the land for their own survival.

63 HVM, 29079, Letter from Paisios Vatopedinos to HVM, 18 July 1923. In his letter, Yero-Paisios noted that he had received by boat the wooden shafts and the coal but not the iron barrels he had requested. Paisios urged his brothers in Vatopedi to send a second ship as soon as possible to collect the rest of the production.

64 R. Clogg, A Concise History of Greece (Cambridge 1992) 93-9.

65 Op. cit, 100-6.

66 HVM, 29080.

67 HVM, 29079. 
Acknowledging the difficult predicament the refugees found themselves in - they experienced high mortality rates- the Athonite monasteries entered into negotiations with the Greek state. The latter believed that the expropriation of monastery estates and their subdivision into smallholdings represented the solution to a huge problem.

Almost a year later, in 1924, the two sides reached an agreement. The Greek state decided to lease all the Athonite estates for a period of ten years, with each monastery retaining just one. ${ }^{68}$ The state had the right to extend the agreement for a number of years. After long negotiations, in 1932 it was decided to expropriate the monastic estates. The Athonite monasteries were compensated, each monastery receiving a bond equal to the estimated value of their confiscated estates. ${ }^{69}$ The bond, named the

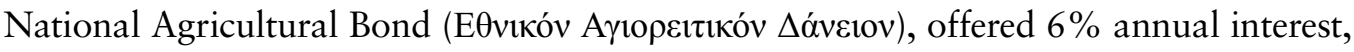
based on the annual turnover of the agricultural production of the monastic estates. After the Second World War, the bond was waived, with all amounts reduced significantly, and replaced by an annual state subsidy that varied from year to year. The most negative outcome of this development was that it made the Athonite monasteries dependent on the Greek state, since they had lost most of their agrarian land and consequently their self-sufficiency. The state expropriated hundreds of thousands of stremmata of monastic arable land.

For its part, Vatopedi entered into a separate negotiation with the state that led to another agreement in $1924,{ }^{70}$ under whose terms it conceded the Souflar and Agios Mamas metochia to the state, which in turn acknowledged the monastery's rights to Lake Bourou (now Lake Vistonida) in the area of Porto Lagos, in Xanthi province. ${ }^{71}$

Although the concession of Souflar was a great blow to Vatopedi's self-reliance, it was an acknowledgment by the monks of the inevitable course of events. For the state, acquiring Souflar was a great opportunity to settle refugees and exploit a huge estate that was fully productive, well organized and a point of reference. Today, the refugee village of Nea Triglia is located in the area.

\section{Conclusion}

It is important to highlight that, during its short life, Souflar Metochi successfully became the main supplier to Vatopedi and made it largely self-sufficient. The long experience of the monks and their hard work facilitated Souflar's organizational structure. Ever

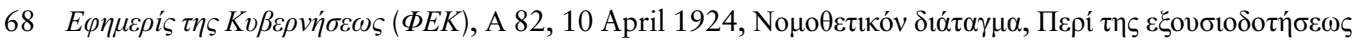

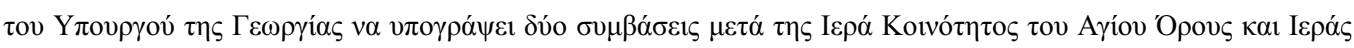

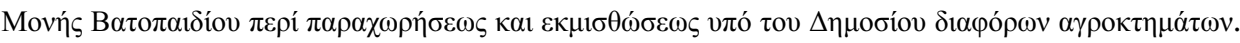

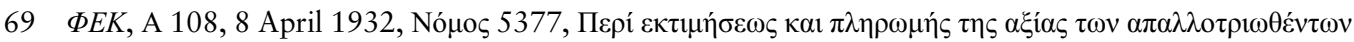

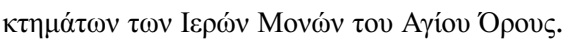

70 Under the provisions of the first agreement, Vatopedi lost its metochia in Pyrgos and Provlakas and kept only the metochi on Ammouliani island in the Athos Gulf. After some time it ceded that also to the Greek state. 71 This agreement was included in the same law containing the provisions for the leasing of the Athonite estates (see n. 68). 


\section{Andreas Bouroutis}

disciplined, the managing monks took initiatives to make agricultural improvements and secure better crops. Marketable surpluses were not sought for but were welcome, while shortages could be rapidly made up by tapping into the output of the geratzides and of the neighbouring villages.

Souflar's success demonstrates its vital economic role in the area. As a solitary large-scale producer, it became a profitable enterprise that involved all the local communities in various ways. In labour relations, it managed to strike a balance between old and new methods, since the monks delegated to manage it did not always adhere to traditional labour relations and, in certain cases, even proposed new means of contracting workers. Beyond the dependent peasants, koligoi and geratzides, the Souflar Metochi cooperated with the neighbouring settlements through the antisporo method and offered its non-cultivated or idle land for winter and summer pasture in lieu of an annual fee. It was a win-win scenario for the local husbandry, lay people and the monastery itself.

Dr. Andreas Bouroutis, a historian-economist, is Lecturer at the Aristotle University of Thessaloniki (School of Political Sciences). Currently he is the Scientific Supervisor of the research programme 'Postwar transformation of Thessaloniki and the fate of Jewish assets'. 